\title{
FIGURY SAMOTNEJ ŻAŁOBY
}

Krzysztof Kieślowski i Roland Barthes: pozornie nie łączy ich nic. Pierwszy zauroczony Francją, jej metafizyką codzienności oglądaną ze wschodnioeuropejskiej perspektywy; drugi jest jednym z najbardziej rozpoznawalnych współczesnych francuskich myślicieli, profesor Collège de France, osierocony przez ojca, stworzył szczególną, trwającą przez całe życie relację z matką. Co zatem może łączyć obie postaci: intelektualne upodobania, staranne przyglądania się życiu, czy też miłość do błękitnego dymu i wyrazistego smaku nieodłącznego papierosa - dziś tak bardzo cenzurowanego, napiętnowanego, podobnie jak wrażliwość, będąca zawsze względem rzeczywistości niedopasowana. Na pewno zainteresowanie śmiercią i żałobą, które dla każdego z nich stało się zarówno szczególnym przedmiotem zainteresowania, jak i bardzo głębokim doświadczeniem.

Rozważania nad problemem śmierci i umierania mają na obszarze humanistyki i badań nad kulturą swoją długą i bogatą tradycję. Śmierć jest tematem rozważań poetów, twórczości artystycznej, problemem podejmowanym zarówno przez teologów, jak i filozofów. Wśród tych ostatnich jedną z najbardziej znanych jest interpretacja Karla Jaspersa uznającego akt umierania za "doświadczenie graniczne". Świat ludzki nie jest bowiem przestrzenią nietykalnych podmiotów, nieustraszonych, wiecznych, lecz tych, których egzystencja przemija i staje na krawędzi, granicy, której przekroczenie jest nieodwołalne, gdyż śmierć stanowi bezwarunkowy i ostateczny kres życia; każdego życia. Graniczność doświadczenia śmierci inspiruje również filmowców, którzy chcąc oswoić to nieredukowalne zjawisko, jednocześnie próbują rozpoznać jego tajemnicę. A tworząc iluzoryczne obrazy śmierci, przybliżają jej rzeczywistość. 
Intencją niniejszego tekstu jest konfrontacja obrazu żałoby, towarzyszącej doświadczeniu śmierci, przedstawionej w Niebieskim Krzysztofa Kieślowskiego (filmie należącym do tryptyku Trzy kolory), z jej językowym, osobistym wyrazem, a mianowicie Dziennikiem żałobnym Rolanda Barthesa. W obu figurach żałoby mamy do czynienia z intymnym światem rozpaczy związanym z utratą najbliższych osób, szczególnym stanem osamotnienia, a jednocześnie z odmiennymi, a jednak rzeczywistymi obrazami "pracy żałoby”. Zarówno w Niebieskim, jak i w Dzienniku Barthesa pojawia się odmienny rytm życia, ściśle związany z melancholią utraty, a wraz z nią nadwrażliwość na świat.

\section{Klasyczna figura żałoby}

Postawy wobec umierania, śmierci oraz obecność żałoby w kulturze - to kwestie, w których najwięcej do powiedzenia mają badacze francuscy. Należący do tej najbardziej rozpoznawalnej grupy tanatologów Philippe Ariès, obok szerokiego spektrum podejmowanych analiz, znaczną część swoich zainteresowań poświęca żałobie, a zwłaszcza jej nieobecności we współczesnej kulturze - zarówno tej oficjalnej, jak i prywatnej. Życie w boleści - gdyż na taki źródłosłów kieruje francuskie słowo deuil - żałoba, spotyka się, jego zdaniem, z powszechnym zakazem, dezakceptacją, wyparciem. Zmarłych nie należy opłakiwać, a przynajmniej nie należy smutku towarzyszącemu stracie okazywać. Kultura współczesna dokonała swoistej konwersji, polegającej na odwróceniu społecznego stosunku względem żałoby. Dawniej społeczna reguła nie dość że nakazywała opłakiwanie, to jednocześnie oczekiwała izolacji, aby w samotności, spokoju, wycofaniu przepracować swój ból. Z kolei dziś normą kulturową jest stygmatyzowanie owego zamknięcia, krytyka wyrażanego bólu i wszelkiej jego manifestacji. Nastawiona na hedonizm kultura odrzuciła doświadczenie i oglądanie cudzego cierpienia. $\mathrm{O}$ tej przemianie Ariès pisze następująco:

Po tysiącach lat obowiązku i potrzeby odbywania żałoby, w rozmaitych okresach bardziej spontanicznej lub bardziej narzuconej, w połowie $X X$ wieku pojawił się jej zakaz. W ciągu jednego pokolenia sytuacja się odwróciła: to, co kazały dawniej czynić wewnętrzne przekonania lub wola ogółu, dziś jest zabronione, to, czego dawniej zabraniano, dziś jest zalecane. Nie wypada już okazywać bólu ani nawet sprawiać wrażenia, ze się go odczuwa'1.

\footnotetext{
${ }^{1}$ P. Ariès, Rozważania o historii śmierci, tłum. K. Marczewska, Warszawa 2007, s. 271.
} 
Milczenie wobec żałoby stało się kulturową normą, w stosunku do której dawne obyczaje regulujące i ułatwiające przeżywanie dramatycznych wydarzeń utraciły swą konstytutywną moc. Traktowana jako patologiczne doświadczenie, żałoba znalazła swoje uzasadnienie we współczesnej psychologii a zwłaszcza psychoanalizie Zygmunta Freuda, której ekonomia stała się inspiracją dla wielu kontynuatorów jego myśli (nie tylko psychologów). To przecież w klasycznym już eseju Żałoba i melancholia Freud opisuje żałobę jako bolesną depresję, stan charakteryzujący się między innymi brakiem zainteresowania światem zewnętrznym, ograniczeniem działań, poczuciem utraty własnej wartości. Oznacza to, że doświadczenie żałoby związane ze śmiercią i stratą ogranicza codzienne funkcjonowanie i raczej wiąże się z wycofaniem niż afirmacją życia. Żałoba:

jest $\mathrm{z}$ reguły reakcją na utratę ukochanej osoby lub podstawianego $\mathrm{w}$ jej miejsce pojęcia abstrakcyjnego jak ojczyzna, wolność, ideał itp. W określonych okolicznościach u niektórych osób, podejrzewanych zatem o predyspozycje chorobowe, zamiast żałoby występuje melancholia. Jest też godne podkreślenia, że nigdy nie zdarza nam się traktować żałoby jako stanu chorobowego i przekazać go lekarzowi w celu kuracji, mimo że niesie on z sobą poważne odstępstwa od normalnych zachowań życiowych. Ufamy, że po pewnym czasie zostanie przezwyciężony i zakłócenie go uważamy za niecelowe, wręcz szkodliwe².

Ta reakcja na utratę radykalnie odwraca dotychczasowy porządek świata, od tej pory widzianego już tylko jako jałowy i pusty. Nie jest on już interesujący, nie bawi, a jedynie rani, nudzi, zamiast zachwycać, wywołuje jedynie strach i pragnienie wycofania się poza jego nawias i dynamikę. Świat przestaje być przestrzenią oczekiwań, a staje się jedynie źródłem oporu przed zmianą, zastąpieniem, zaangażowaniem. Jest miejscem zubożałym o bezpowrotnie utracony obiekt, $\mathrm{w}$ którym to miejscu podmiot musi na nowo ukonstytuować siebie, na powrót - lecz już w inny sposób - osadzić się w świecie, który w stanie żałoby stanowić będzie wyzwanie.

Uniwersalizm śmierci, a jednocześnie indywidualizm żałoby stały się również wyzwaniem dla wyobrażeń i narracji filmowych. Oba doświadczenia, skupiające w sobie retorykę pamięci, stały się dla kina, które chce dotykać egzystencjałów, wyzwaniem, odkrywaniem nowych wrażliwości i przekraczaniem granic. Gilles Deleuze pisze:

Między dwoma obliczami absolutu, pomiędzy dwiema śmierciami - śmierci od wewnątrz, czyli przeszłości, i śmierci z zewnątrz, czyli przyszłości - wewnętrzne obsza-

2 S. Freud, Żałoba i melancholia, tłum. B. Kocowska, [w:] K. Pospiszył, Zygmunt Freud. Człowiek $i$ dzieło, Wrocław - Warszawa - Kraków 1991, s. 295. 
ry pamięci i zewnętrzne pokłady rzeczywistości zmieszają się, poszerzą, zerwą i utworzą całość niestałego życia, obejmującego zarówno kosmos, jak i umysł, wysyłającego rozbłyski od bieguna do bieguna ${ }^{3}$.

Film zdawał się zrealizować jedno z największych ludzkich pragnień marzenie o pochwyceniu czasu, zatrzymaniu przemijania, utrwaleniu upływających chwil, zabalsamowaniu jednorazowych zdarzeń. Jednorazowy ruch, w przeciwieństwie do znieruchomiałej fotografii, jest zwielokrotniony i utrwalony na celuloidowej taśmie wiernie odtwarzającej zatrzymaną materię. Film dokonuje repliki rzeczywistości z jej fakturami i zmiennością. Kino spowodowało, że każdy człowiek zyskał szansę odtworzenia, zwielokrotnienia przeżyć, niepokoju, emocji, które wcześniej wydawały mu się jedynie własnymi, osamotnionymi. W kinie zobaczył na nowo siebie $\mathrm{z}$ wszelkimi doznaniami, które, jak się okazuje, są doświadczeniem wielu. Czy ta obecność, prezentacja czasu teraźniejszego, który zrywa z przeszłością, a jednocześnie nie programuje przyszłości, nie jest melancholijnym uśpieniem, hipnozą, o której z kolei tak pisał Roland Barthes:

Wszystko dzieje się tak, jakby jeszcze przed wejściem widza na salę połączyły się wszystkie klasyczne warunki hipnozy: pustka, bezczynność, brak zajęcia: to nie wobec filmu i przez film się marzy; czyni się to nieświadomie, zanim się zostanie widzem. [...] Kontynuując te prawdziwą metonimię, można stwierdzić, iż czerń sali jest prefigurowana przez „mroczne marzenie”, [...] które poprzedza tę czerń i prowadzi podmiot od ulicy do ulicy, od afisza do afisza, aby w końcu pogrążył się w ciemnym, anonimowym, niezróżnicowanym sześcianie, w którym musi powstawać ten festiwal uczuć, nazywany filmem4.

Czy kino zatem więzi jak żałoba? Unieruchamia w czasie, teraźniejszości, która dzieje się poza codziennym doświadczeniem? Jak obraz radzi sobie z osamotnionym doświadczeniem żałoby i czy jest ona możliwa do wypowiedzenia za jego pomocą?

\section{Oglądanie żałoby}

Krytycy i filmoznawcy wielokrotnie podkreślają, że filmy Krzysztofa Kieślowskiego w pewien sposób są filmami o żałobie, gdyż cechują je: osadzenie w czasie, dramatyczność filmowanej historii, bohatero-

\footnotetext{
${ }^{3}$ G. Deleuze, Kino: 1. Obraz-ruch 2. Obraz-czas, tłum. J. Margański, Gdańsk 2008, s. 427.

${ }^{4}$ R. Barthes, Wychodzac z kina, tłum. Ł. Demby, [w:] Interpretacja dzieła filmowego. Antologia przekładów, red. W. Godzic, Kraków 1993, s. 157.
} 
wie konstytuowani przez śmierć. I mimo że pozostają one poza mimetycznymi ramami i konwencją, to zawierają w sobie jej przedstawienie. Obrazy Kieślowskiego, pozostając osadzone w melancholijnej retoryce, stają się jednocześnie „władczym znakiem przyszłej śmierci”, o którym pisał Barthes. Dlatego też spróbuję wskazać, na ile przedstawione w Dzienniku żałobnym doświadczenie żałoby i emocje z nim związane są analogiczne do traumy bohaterki Niebieskiego. Na ile te dwie formy wypowiedzi - słowo i obraz uzupełniają się i jak bardzo przybliżają sens śmierci i logikę żałoby.

Niebieski Kieślowskiego, należący do tak zwanej francuskiej serii filmów reżysera, jest obrazem, w który wpisana jest świadomość bliskiej własnej śmierci. Tym samym Kieślowski swoją wizją filmowego świata wpisuje się w koncepcję kina przedstawioną Gilles'a Deleuze'a. Dla francuskiego badacza, kino, mające charakter otwarty i dynamiczny, jednocześnie pobudza i odkrywa to, co mentalne i duchowe. Poprzez filmowe zapośredniczenie, które podlega bezustannej interpretacji i reinterpretacji, widz jest sprowokowany do kolejnego przedyskutowania tych treści, które konstytuują jego własne, intymne istnienie. Życie - także to filmowe - jest obrazem, którego trwanie rozpięte jest pomiędzy ramami życia i śmierci, otwiera się na nieskończoność wariantów i możliwości. Uwzględniając to teoretyczne zaplecze, warto przypomnieć, że reżyser wielokrotnie deklarował, że każdy film jest jednocześnie opowieścią o fragmencie jego samego, a kamera wielokrotnie skupia się na jego własnym życiu z wszystkimi jego emocjami, pragnieniami czy niepokojami. Żałoba, wpisująca się w porządek doświadczenia śmierci, w filmie Kieślowskiego odarta jest wszelkich cech mimetyczności jest raczej zasugerowana niż przedstawiona, czyniąc jej doświadczanie jeszcze bardziej samotnym i pustym. Reżyser odziera ją z tradycyjnych akcesoriów, a jednocześnie czyni wszechobecną, przenikającą widza swym błękitnym chłodem poprzez wprowadzenie go w grę nastrojów i wariantów. Tytułowy kolor filmu, a jednocześnie barwa żałoby, otwiera jedną z wielu możliwości interpretacji, lecz sam Kieślowski nie traktował jej arbitralnie. Jak mówił w wywiadzie:

Okazuje się [...], że dla Portugalczyka kolor niebieski to jest kolor szczęścia, dla Anglika i Amerykanina kolor niebieski to blue, czyli "smutny", blues się z tego bierze, dla Hindusów niebieski to kolor nadziei. [...] Okazuje się, że zależnie od tego, gdzie kto mieszka, w jakim klimacie, jak się toczyła jego historia, jego kraju, jego świata, to ten kolor znaczy zupełnie co innego ${ }^{5}$.

5 „Ponieważ są ciagle ci ludzie..." z Krzysztofem Kieślowskim rozmawiali A. Otrębska i J. Błach, [w:] Kino Krzysztofa Kieślowskiego, red. T. Lubelski, Kraków 1997, s. 292. 
Wybierając spośród tych różnorodnych interpretacyjnych gier, podążę tropem akcentującym melancholię błękitu. Uwzględniając obecność błękitnych przedmiotów, którymi otacza się bohaterka - błękit jest także kolorem trudnej wolności, na którą Julie jest skazana - uznać należy, że Niebieski jest opowieścią o samotnej żałobie. To jej nastrojowi podporządkowana jest narracja filmu, codzienność i metafizyka, które są śladem dramatycznego doświadczenia bohaterki. Julie, 33-letnią młodą kobietę, spotyka bowiem prawdziwa tragedia - jej mąż, będący wybitnym kompozytorem, i ich jedyna pięcioletnia córka giną $\mathrm{w}$ wypadku samochodowym, $\mathrm{z}$ którego ona sama wychodzi właściwie bez uszczerbku. Jej dotychczasowe, ustabilizowane, zamożne i piękne życie kończy się w chwili, gdy powinno być - i zapewne było - najszczęśliwsze. Pozostaje sama, dramatycznie uwolniona od bliskich, zmuszona do przepracowania swej żałobnej sytuacji. Nie mając odwagi ze sobą skończyć - pomimo podjętej próby samobójczej, która w tym przypadku byłaby zrozumiała, a wręcz spodziewana - postanawia skończyć ze swoją przeszłością. Nawiązując do standardowej psychologii kolorów: niebieski, oznaczający separację, chłód i wycofanie, ma tutaj swoje uzasadnienie - Julie jest niejako wrzucona w sytuację izolacji, którą dodatkowo wzmacnia poprzez wycofanie się ze świata i zawieszenie relacji z jakąkolwiek wspólnotą. Julie znajduje się w sytuacji, o której tak pisze Julia Kristeva:

[Depresja daje mi] pozbawione życia istnienie, które, jakkolwiek niekiedy poruszone wysiłkiem, jaki czynię, aby je przedłużyć, w każdej chwili gotowe jest zapaść się w śmierć. Śmierć jak zemsta albo śmierć jak wyzwolenie jest jedynie wewnętrznym progiem mojego przygnębienia, niemożliwym sensem tego życia, którego brzemię nieustannie wydaje mi się nie do zniesienia, pomiędzy tymi chwilami, kiedy zbieram się w sobie, by stanąć twarzą w twarz z nieszczęściem. Przezywam żywą śmierć, moje ciało jest rozdarte, krwawiące, strupieszałe, mój rytm spowolniony lub zawieszony, wymazały albo nabrzmiały, czas zostaje wchłonięty przez udrękę ${ }^{6}$.

Wpisując się tę narrację "utraty bytu"7, Julie dobrowolnie postanawia rozpocząć nowe życie jako kolejny, anonimowy mieszkaniec paryskiej dzielnicy. Zrywa wszelkie więzi, a dla wzmocnienia anonimowości wynajmuje mieszkanie pod zmienionym nazwiskiem. Zrywa ze swoją historią, przeszłością, wspomnieniami, żyje bez planów na przyszłość, jedynie w teraźniejszości, nie robiąc "zupełnie nic" - jak mówi agentowi mieszkaniowemu. Bohaterka, dokonując tak radykalnej izolacji, odwraca dotychcza-

${ }^{6}$ J. Kristeva, Czarne słońce. Depresja i melancholia, tłum. M.P. Markowski, Universitas, Kraków 2007, s. 5-6.

7 Ibidem, s. 6. 
sowy porządek swojego świata,a jednocześnie tworzy klasyczną przestrzeń dla przepracowania swojej żałoby. Odreagowując traumatyczne doświadczenie, pozbywa się jakichkolwiek pamiątek: mebli, domu, fotografii, które mogłyby przywoływać wspomnienia. Odżegnuje się od swojej pamięci, przekraczając jednak, swym radykalnym brakiem afirmacji, jeden z klasycznych scenariuszy żałoby: nie uczestniczy w pogrzebie, nie odwiedza cmentarza, nie płacze, co zarzuca jej nawet stara służąca. Nie ogląda fotografii, wręcz gardzi nimi, gdy pozwala współpracownikowi męża zabrać teczkę z całą zawartością, która, jak później się okaże, zawierała w sobie pozamałżeńską tajemnicę. Jej neurotyczna samotność służy tu raczej skonstruowaniu nowej podmiotowości, która nie będzie uwikłana w przeszłość - Julie umiera dla świata tak prywatnego, w którym nie poznaje jej nawet chora matka, jak i publicznego. Jej stosunek do pamięci jest radykalnie różny niż w przypadku Rolanda Barthesa, dla którego właśnie fotografia, jako depozytariuszka przeszłości, była budulcem jego żałoby:

W pewien listopadowy wieczór, niedługo po śmierci mojej matki, porządkowałem zdjęcia. Nie liczyłem na to, że ją "odnajdę", nie oczekiwałem niczego od "tych zdjęć, które słabiej wywołują wspomnienie osoby, niż samo tylko myślenie o niej". Dobrze wiedziałem o tej fatalności, która jest jedną z najbardziej okrutnych stron żałoby: że chociaż będę wpatrywał się w te obrazy, nie będę mógł już nigdy przypomnieć sobie jej rysów ${ }^{8}$.

Neurasteniczność Julie polega na zmierzaniu do radykalnego zapomnienia, zatrzaśnięcia przeszłości, by uformować nową siebie. Pomimo podejmowanych $\mathrm{z}$ takim wysiłkiem starań, kobieta pozostaje jednak niewolnikiem swojej pamięci. To muzyczne cytaty z niedokończonego dzieła jej męża (a może własnego?) powracają $\mathrm{w}$ jej pamięci niczym reminiscencje przeszłości. Muzyka staje się tutaj bolesnym requiem i radosnym hymnem jednocześnie, gdyż to ona pozwala bohaterce przepracować żałobę, dzięki czemu, jak

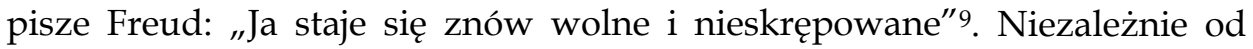
tego, czy uzna się Julie za prawdziwą i jedyną autorkę powstającej muzyki, to ona właśnie uniemożliwia jej rezygnację ze wszystkiego. Powracające dźwięki kompozycji, które stają się kluczowym bohaterem filmu, udaremniają całkowitą eliminację przeszłości. Wraz z zaangażowaniem w pracę nad partyturą pojawia się u bohaterki możliwość przepracowania straty, a wraz $\mathrm{z}$ nią afirmacja życia, która najpełniej realizuje się w przekazaniu domu ciężarnej Sandrine, o której istnieniu Julie dowiedziała się z odrzuconych wcze-

8 R. Barthes, Światto obrazu. Uwagi o fotografii, tłum. J. Trznadel, Warszawa 1996, s. 109.

${ }^{9}$ S. Freud, op. cit., s. 296 
śniej fotografii, i propozycji nadania nazwiska męża jej dziecku,. Dzięki tej długiej - przechodzącej przez fazę buntu, izolacji, skrajnej samotności, aż po głębokie przepracowanie - żałobie, Julie zaczyna być "domknięta". Płacz bohaterki, utrwalony w ostatnich scenach, kiedy może już sobie ona na niego emocjonalnie pozwolić, sprawia, że oddalenie od świata powoli, lecz nieuchronnie ustępuje naturalnemu cyklowi życia: narodzin i śmierci.

\section{Opisać samotność żałoby}

Julie, poprzez zaangażowanie $\mathrm{w}$ kompozycję, partyturę, która jest pozostawionym do zrealizowania testamentem, nie odzyskuje utraconej przeszłości, a jej przestrzeń pozostaje naznaczona stratą. Utracony czas nie powraca, jej życie, a wraz z tym filmowy obraz, pozostaje naznaczone melancholią. Pamięć staje się tu przekleństwem, którego bohaterka stara się unikać. Zupełnie przeciwstawną postawę można zaobserwować $\mathrm{w}$ narracji Rolanda Barthesa, u którego żałoba zawsze jest uwikłana $\mathrm{w}$ pamięć, a ta z kolei pozostaje protezą obecności. „Fotografia nie przypomina przeszłości” - pisze Barthes. „W jej działaniu na mnie nie chodzi o odbudowanie tego, co runęło (w wyniku działania czasu, odległości), a jedynie o poświadczenie, że to, co widzę - naprawdę istniało"10. Fotografia, pozostająca względem kina starszą siostrą, staje się dla francuskiego semiotyka pretekstem do wspomnień, a nawet czerpania z żałoby swoistej rozkoszy, której świadkiem, podobnie jak u Julie, jest Paryż. Osamotnieni w swym doświadczeniu, w mieście szukają oni ucieczki przed światem, który ich przerasta, tu budują sobie poczucie bezpieczeństwa:

Podobnie jak miłość, żałoba uderza w świat, w towarzystwo, irrealnością, natręctwem. Stawiam opór światu, cierpię od tego, czego ode mnie żąda, od jego żądania.

Świat powiększa mój smutek, moją oschłość, moje zagubienie, moją irytację etc. Świat mnie przygnębia11.

Pierwsze słowa Dziennika żałobnego brzmią: „Pierwsza noc poślubna. Ale pierwsza noc żałobna?" (s. 15). Ten wpis datowany jest na 26 października 1977 roku. Henriette Barthes, matka Rolanda, umarła dzień wcześniej, zapoczątkowując tym samym zupełnie nowy etap w życiu francuskiego myśliciela. Ten okres życia Barthesa - podobnie jak u bohaterki Kieślowskiego układa się według innego rytmu: samotnego, melancholijnego, żałobnego. Notatki Dziennika - pisane odręcznie, ołówkiem lub piórem, na fiszkach -

${ }^{10}$ R. Barthes, Światto obrazu, op. cit., s. 138-139.

${ }_{11}$ R. Barthes, Dziennik żałobny, tłum. K.M. Jaksender, Wrocław 2013, s. 139. Dalsze cytaty $\mathrm{z}$ tej pozycji lokalizuję bezpośrednio $\mathrm{w}$ tekście, podając numer strony. 
obejmują okres blisko dwóch lat - ostatnia datowana kartka dziennika przypada na 15 września 1979 roku. Pół roku później, 25 marca 1980 roku, Roland Barthes umiera. Ostatnie lata życia i powstające w tym czasie zapiski autora Przyjemności tekstu uwikłane są w szczególny, intymny dyskurs, który bezpośrednio związany jest z jego osobistą kondycją - struktura dziennika i włączone w nią doświadczenia stanowią swoistego rodzaju klamrę wyznaczająca granice jego egzystencji. Wypowiedzi Barthesa wkraczają tu poza teoretyczny, literacki i filozoficzny zakres, dotykając delikatnych i najwrażliwszych części ludzkiego istnienia. Pisanie jest tu zawsze odnoszone do żałoby, która stanie staje się nieznaną wcześniej częścią życia autora Dziennika. Brak oswojenia żałoby przejawia się w samej formie zapisu - luźno układanych kartek, których treść i ascetyczna forma wyrazu najczęściej przypomina haiku, impresję, urwaną myśl. Ta forma pracy i prowadzenia notatek nie była Barthesowi obca, praktykował ją przecież, jak i wielu innych myślicieli, na co dzień. $Z$ dokładnie tak samo utkanych zapisków skonstruowana jest autobiograficzna książka zatytułowana Roland Barthes, $\mathrm{w}$ tym jednak przypadku świadomie i pamiętając o intencji publikacji, fiszki zostały przez autora uporządkowane i zredagowane. Zapiski stanowiące Dziennik żałobny nie zostaną nigdy poddane redakcyjnej obróbce, autorskiej korekcie i akceptacji, po której mogłyby zostać, za przyzwoleniem autora, opublikowane. Pierwsza francuska edycja nastąpi dopiero w 2009 roku, a redakcji podejmie się Natalie Leger.

Praca pisania była dla Barthesa tym samym, czym dla Julie komponowanie: trwaniem w świecie - izolowanym, samotnym (Barthes napisze: „Nie pragnę, lecz potrzebuję samotności" [s. 103]), a jednocześnie próbą zachowania więzi z utraconym. Wbrew definicji procesu żałoby, zgodnie z którą miałaby być ona zdarzeniem, Barthes zanurza się w niej coraz głębiej, zamieniając ją na trwanie. Żałoba staje się regułą jego życia i pisania. Barthes nie realizuje swojego wielkiego projektu - napisania powieści, ale skupia się na fragmentach, w przeciwieństwie do Julie, która kończy wielką, muzyczną kompozycję. Nie mogąc napisać literackiego dzieła, Barthes konstruuje językowe impresje, westchnienia, afirmując swoją niemoc: „Od śmierci mamy żadnej ochoty budowania czegokolwiek. Dlaczego? Literatura = jedyna dziedzina szlachetności (tak jak była nią mama)" (s. 238). Pisane w tym czasie Światło obrazu jest brzemieniem żałoby, konsekwentnie deponuje ono w sobie utratę. Fotografia matki, stanowiąca punkt wyjścia dla rozważań z drugiej części Światła obrazu, staje się również powracającym refrenem Dziennika: „Otrzymawszy wczoraj zdjęcie mamy jako małej dziewczynki w ogrodzie zimowym Chennevieres, o którego kopię się starałem, próbuję ustawić je przed sobą na biurku. Ale to za dużo, to dla mnie nie do przyjęcia, sprawia mi to za dużo bólu" (s. 229). 
Podejmując retorykę separacji, Barthes nie oczekuje od pisma terapeutycznych rezultatów, podobnie jak, w przypadku kompozycji, nie spodziewa się tego Julie. Wprost przeciwnie, uwewnętrznienie doświadczenia zdaje się przybliżać autora Imperium znaków do zmarłej. Wręcz narcystycznie oddala się on od świata w głąb żałoby, która strukturyzuje jego życie, znajdując w niej szczególne upodobanie i docierając do sedna obecności pozbawionej zapośredniczenia znaków. Fragmentaryczność i nagość pisma Dziennika, znajdująca się na krawędzi wypowiadalności i emocjonalnego ekshibicjonizmu, zawiera jednocześnie w sobie uniwersalizm doświadczenia. 18 lipca 1978 roku Barthes notuje: „Każdemu jego własny rytm zgryzoty” (s. 176). Narracyjny rytm żałoby jest zindywidualizowany, osobisty, własny, a przez to samotny. Barthes przeżywa własną pustkę, zdając sobie sprawę, że uczestniczy w powszechnie przeżywanym doświadczeniu - indywidualnym i podzielanym jednocześnie. Jego wypowiedź jest indywidualnym świadectwem, ale jednocześnie udowadnia, że wszyscy jesteśmy tacy sami. Zdając sobie z tego sprawę, swoją zgryzotę uznaje za banalną, odartą z estetycznej izolacji: "Robiąc te zapiski, powierzam się banalności, która jest we mnie" (s. 29), i dalej: „Śmierć, Zgryzota nie są niczym innym niż banałami” (s. 235).

Dla Barthesa, podobnie jak dla bohaterki Kieślowskiego, śmierć powiązana jest z uwolnieniem. Julie, odseparowana od męża i zamkniętej przeszłości, afirmuje swą bolesną autonomię. Próbuje życia bez pragnień, zobowiązań, przeszłości. Z kolei Barthes wspomina, iż śmierć wyzwala z zależności, uwikłania w drugą osobę. Oboje uznają jednak, iż wraz z upływem czasu niezależność ta traci swój smak, ustępując egoizmowi, który nie przynosi ulgi. Tę przynosi dopiero płacz, który do Julie przychodzi z czasem, dla Rolanda zaś jest codziennym doświadczeniem we wczesnej fazie osamotnienia, tak jak oglądanie fotografii, odwiedzanie cmentarza, wspominanie rytuałów. Lecz o ile Niebieski, w konsekwencji, wyraża rezygnację z pesymistycznej melancholijnej postawy, o tyle u Barthesa, pomimo symptomów pracy żałoby, życie ukierunkowuje się w stronę pragnienia śmierci, która niebawem nadchodzi.

\section{Figures of Lonely Mourning}

Summary

The intention of the author of this paper is to juxtapose the image of mourning that accompanies the experience of death as represented in Blue, a film directed by Krzysztof Kieślowski, as a part of a The Three Colors Trilogy, and its personal linguistic expression in The Mourning Diary by Ronald Barthes. Both figures of mourning 
render to us an intimate world of mourning linked to a loss of somebody dear and express a peculiar state of exclusion as well as various yet real images of mourning "at work". In both Blue and The Mourning Diary we are exposed to a different rhythm of life closely linked to the melancholy of loss and a resultant vulnerability of the mourner towards the world. 